\title{
Population decline and range contraction of the Egyptian Vulture Neophron percnopterus in the Balkan Peninsula
}

\author{
METODIJA VELEVSKI, STOYAN C. NIKOLOV, BEN HALLMANN, \\ VLADIMIR DOBREV, LAVRENTIS SIDIROPOULOS, VICTORIA SARAVIA, \\ RIGAS TSIAKIRIS, VOLEN ARKUMAREV, ANTONIA GALANAKI, \\ THEODOROS KOMINOS, KALLIOPI STARA, ELZBIETA KRET, \\ BRATISLAV GRUBAČ, EMANUEL LISIČANEC, THANOS KASTRITIS, \\ DIMITRIS VAVYLIS, MIRJAN TOPI, BLEDI HOXHA and STEFFEN OPPEL
}

\begin{abstract}
Summary
The Egyptian Vulture has been classified as 'Endangered' due to a rapid population decline in India and long term declines in Europe and Africa. Although the species has been reported to be declining in Eastern Europe, no quantitative assessment of the magnitude or the causes for population declines are available. We used monitoring data from the Balkan Peninsula to estimate changes in population size and extent of occurrence of Egyptian Vultures between 1980 and 2013. We quantified population trends in three countries (Bulgaria, Greece and the former Yugoslav Republic [FYR] of Macedonia) to assess whether population declines are similar within the Balkan range states. We found a rapid and consistent decline of the Egyptian Vulture population that was largely similar among the three countries $(\lambda=0.940$ in FYR of Macedonia, 0.951 in Bulgaria, 0.920 in Greece). As a consequence of population declines, the breeding range of Egyptian Vultures has contracted and the population in the Balkan Peninsula has fragmented into six subpopulations separated by more than $80 \mathrm{~km}$. Population declines may be driven by factors such as poisoning, electrocution, direct persecution and changes in food availability which operate at large spatial scales and affect birds both on breeding grounds as well as during migration and wintering. Because the relative importance of threats to the survival of Egyptian Vultures are poorly understood, there is a critical need for research into causes of mortality and potential conservation actions that may halt and reverse population declines.
\end{abstract}

\section{Introduction}

Many raptor species around the world are declining and large scavengers such as vultures have shown some of the strongest population declines (Prakash et al. 2003, Thiollay 2006, Virani et al. 2011, Ogada et al. 2012). The Egyptian Vulture Neophron percnopterus is a relatively small vulture with a broad distribution throughout the southern Palearctic and North Africa, and populations of this species are declining throughout its range. West African populations declined by about $86 \%$ between 1969 and 2004 (Thiollay 2006, 2007, Virani et al. 2011), and the population in India declined by 80\% between 1999 and 2003 (Cuthbert et al. 2006). As a consequence of the long term decline in Europe and West Africa and the rapid decline in India, the species is listed as globally 'Endangered' (BirdLife International 2014). 
Egyptian Vultures used to be widely distributed throughout southern Europe, and the current breeding population is estimated at 3,300-5,050 breeding pairs (Iñigo et al. 2008). The largest European populations are in Spain and Turkey $(1,270-1,300$ and $1,500-3,000$ pairs, respectively, Iñigo et al. 2008), and the trend of the Spanish population differs between regions (Donázar 2004). However, little is known about the size and population trajectory of Egyptian Vultures in Eastern Europe. The Egyptian Vulture used to be common in all Balkan countries (Patev 1950, Grubač 1989, Handrinos and Akriotis 1997, Grubač 2000), but declines have been documented in Bulgaria (Kurtev et al. 2007), Greece (Vlachos et al. 1998) and the Former Yugoslav Republic of Macedonia (hereafter FYR of Macedonia, Grubač et al. 2014). The species became extinct in Croatia (Sušić 1993), Montenegro (last observation from 1991; Ljucović 1995), Bosnia and Herzegovina (last observation from 1989; Marinković et al. 2007), and probably in Serbia (last confirmed breeding in 1999; Grubač 1999). However, there is no current quantitative synthesis of the population status and trends of Egyptian Vultures in different Balkan countries.

In this paper, we collated Egyptian Vulture monitoring data from three Balkan countries (Bulgaria, Greece and the FYR of Macedonia) and estimated population trends using a state-space model. We hypothesized that the spatial distribution of Egyptian Vultures has declined over the past decades and that the current population became fragmented. We used the results of our analysis to discuss the possible underlying causes of the similar population trends across the countries and the need for conservation action.

\section{Methods}

\section{Population monitoring}

Breeding territories of Egyptian Vultures have been monitored in several Balkan countries with varying intensity since 1980 . We first collated monitoring and distribution data from published sources (Sušić 1993, Ljucović 1995, Handrinos and Akriotis 1997, Grubač 1999, Marinković et al. 2007, Kurtev et al. 2007, 2008, Xirouchakis and Tsiakiris 2009, Skartsi et al. 2010, Poirazidis et al. 2011, Grubač et al. 2014) and complemented these data with unpublished data collected by the authors. Breeding territories were generally monitored during the breeding season (between April and August). Each known or potential territory was visited at least once during a breeding season to determine the presence or absence of a breeding pair. The data prior to 2003 were often collected with lower intensity and survey effort, or collated from a variety of sources and confirmed breeding territories. Some of the historic data may thus understate the actual population size in a given year, and it is therefore possible that populations in the past were marginally larger and our trend estimates should therefore be considered as conservative.

Because some historic data reported population sizes either as number of pairs or occupied territories, we assumed that all occupied territories consisted of pairs and used the number of pairs as our unit of population size.

\section{Estimation of trends}

For Bulgaria, Greece and the FYR of Macedonia, good quality monitoring data were available that facilitated quantitative trend estimation. We used the longest available time series of population counts for each country, dating back to 1980 (Bulgaria and Greece) and 1983 (the FYR of Macedonia), to estimate the rate of population change. Before 2003, data were available only for some years in which survey effort had sufficient spatial coverage and intensity. Because the quality of monitoring data in Bulgaria and the FYR of Macedonia improved considerably after 2002, we separately estimated trends also for the time period 2003-2013 in these two countries.

We estimated the population growth rate $(\lambda)$ for each country by using a hierarchical statespace model for population counts, which separated the Egyptian Vulture monitoring data into a population process and an observation error component (De Valpine 2003, Clark and Bjørnstad 2004, 
Kéry and Schaub 2012). State-space models allow a more accurate estimate of population trend than standard linear models because they explicitly allow for environmental stochasticity (Wilson et al. 2011, Kéry and Schaub 2012). Briefly, a state-space model assumes that the annual population growth rate is a realisation from a normal random process, and uses the observed data to estimate the mean and variance of this process. The model thus provides an estimate of population size and growth rate for each year even if data are missing, but the estimates are much more precise for years in which data exist because the estimates can be constrained. State-space models are therefore ideal to estimate trends from time series with missing data, as was the case for our historic vulture data. The overall trend for each country was estimated by averaging the annual growth rate estimates for that country. Although the historic monitoring data did not overlap temporally in the three target countries, we used estimated population sizes for each country to derive a total population size for each year. The overall trend of the Balkan population was then estimated with the total population size in the same way as the country-specific trends were estimated.

We implemented the state-space model in a Bayesian framework to properly account for error propagation when summing population sizes and averaging growth rates over time and across the three countries. We fitted the state-space models using Markov chain Monte Carlo methods in JAGS 3.3 (Plummer 2012) via the R2jags library (Su and Yajima 2012) in R 3.0.I (R Core Team 2013). We ran three Markov chains each with 5,000,000 iterations and discarded the first 2,500,000 iterations to ensure that the models converged. From the remaining iterations we only used every $25^{\text {th }}$ iteration for inference, and we report results as the posterior median and $95 \%$ credible intervals (Kéry and Schaub 2012). Convergence was tested using the Gelman-Rubin diagnostic (Brooks and Gelman 1998), and all reported parameters had values of R-hat $<1$.02. The computer code to repeat this analysis is provided in the online supplementary material; the raw data are provided in Table 1 .

\section{Spatial distribution data}

The coordinates of Egyptian Vulture nests or territories have been recorded in most Balkan countries since the mid 1980s, either by using detailed topographic maps or (since the 2000s) using handheld GPS receivers. We compiled historic (1980-1990) and recent (2012-2013) distribution

Table 1. Number of Egyptian Vulture breeding pairs in the three focal countries in the Balkan Peninsula.

\begin{tabular}{llll}
\hline & Bulgaria & Greece & FYR of Macedonia \\
\hline 1980 & 150 & 250 & \\
1983 & & & 137 \\
1985 & & 225 & \\
1989 & 95 & & 97 \\
1991 & & 175 & 67 \\
1992 & & & \\
1994 & & 150 & \\
1995 & & 140 & 38 \\
1996 & & & 34 \\
2003 & 57 & & 31 \\
2004 & 49 & & 31 \\
2005 & 41 & & 28 \\
2006 & 40 & 29 & 27 \\
2007 & 39 & 25 & 25 \\
2008 & 34 & 21 & 22 \\
2009 & 32 & 17 & 21 \\
2010 & 33 & 15 & 21 \\
2011 & 32 & 12 & \\
2012 & 29 & & \\
2013 & 26 & & \\
\hline
\end{tabular}


data to delineate the extent of occurrence of the Egyptian Vulture in the Balkan Peninsula in these two periods. We assumed that all territories occupied in recent years were also occupied in the past, because high quality territories are generally very persistent (Carrete et al. 2007). For the recent period, we pooled territories into continuous spatial aggregations of territories (hereafter referred to as 'clusters') that contained > I active territory and were separated by a considerable distance, and we report the number of unique clusters, the number of territories in each cluster, and the nearest distance between adjacent clusters.

\section{Results}

A consistent long-term decline of the Egyptian Vulture population was observed in all Balkan countries, and the average population growth rate over the past three decades across the three focal countries was 0.937 ( $95 \% \mathrm{CrI} 0.920-0.957$, Figure 1 ). Mean annual growth rates $(\lambda)$ were largely similar in the FYR of Macedonia (0.940, 95\% CrI 0.920-0.961), Bulgaria (0.951, 95\% CrI 0.927-0.976), and Greece (0.920, 95\% CrI 0.877-0.973) (Table 1). The population trend for the period 2003-2013, where the data quality was high for Bulgaria and the FYR of Macedonia, confirmed the similarity in the annual growth rates between the two countries (0.930, $95 \%$ CrI 0.922-0.948 and 0.943, 95\% CrI 0.935-0.948, respectively).

Qualitative data from Albania, where 20 pairs were recorded in 2006, but only 9 pairs were confirmed in 2012-2013, suggest similar decline rates in other Balkan countries. The range of Egyptian Vultures in the Balkan Peninsula shrank considerably between 1980 and 2013, and all territories in Croatia, Bosnia and Herzegovina, Montenegro, Serbia, and in north-western Bulgaria were abandoned (Figure 2). Thirty years ago, the Egyptian Vulture occurred in a single, more or less spatially continuous population in the Balkan Peninsula. In 2012 and 2013, the occurrence pattern had shrunk to three core areas with $>10$ active territories and three relict clusters with 2-6 active territories (Table 2), plus two single isolated pairs in Greece and northern Bulgaria (Figure 2).

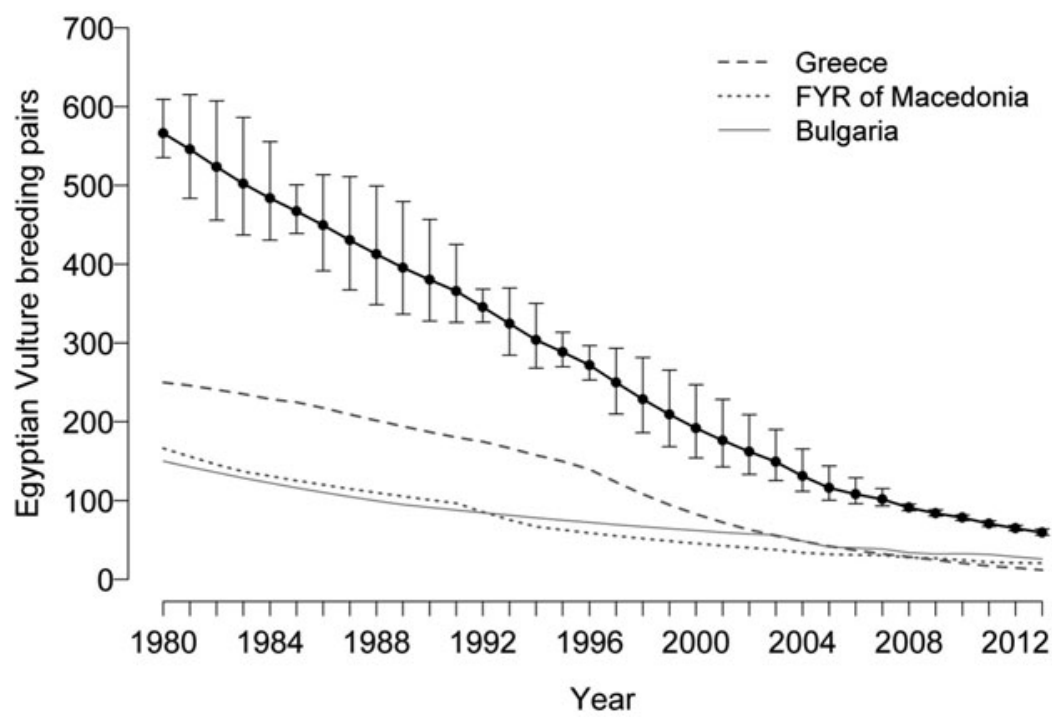

Figure 1. Estimated population size and trajectory of the Egyptian Vulture population summed across three countries in the Balkan Peninsula (black solid line and points), and for each country separately (dark grey lines). Points and lines are median posterior estimates from a Bayesian state-space model fitted to population counts; error bars reflect $95 \%$ credible intervals. 


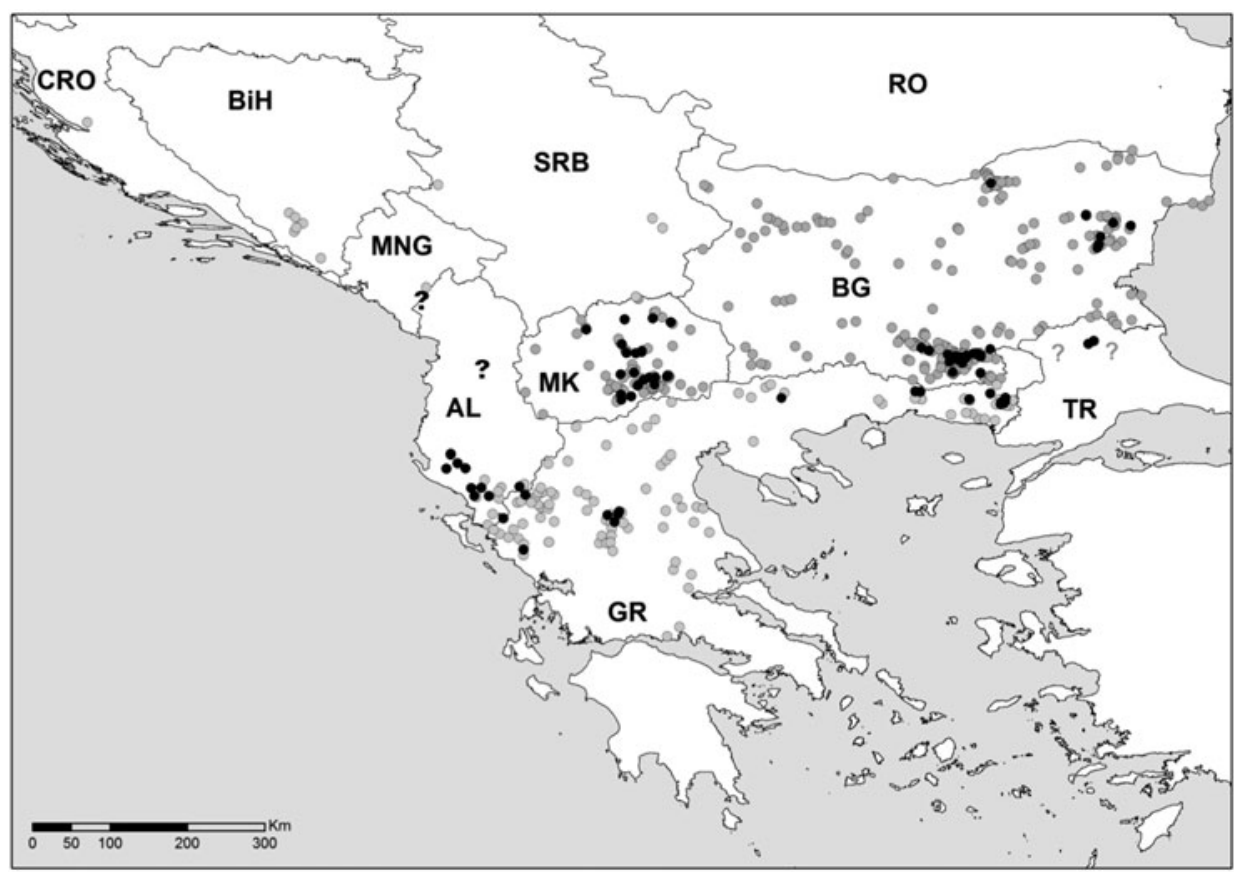

Figure 2. Historic and recent distribution of Egyptian Vulture breeding territories in the Balkan Peninsula. Black circles - active territories in 2012-2013, grey circles - territories occupied 1980-1990, but no longer occupied in 2012-2013. AL - Albania, BG - Bulgaria, BiH - Bosnia and Herzegovina, CRO - Croatia, GR - Greece, MK - the FYR of Macedonia, MNG - Montenegro, RO - Romania, SRB - Serbia, TR - Turkey. Question marks indicate data gaps for historic (grey) or current (black) distribution.

\section{Discussion}

Our findings provide evidence that the Egyptian Vulture population in the Balkan Peninsula has declined by about $4-8 \%$ per year over the past three decades, continuing a long-term decline that started more than six decades ago (Nisbet and Smout 1957). We found similar long-term population decline rates between the FYR of Macedonia, Greece, and Bulgaria, suggesting that over the past three decades Egyptian Vultures were exposed to large scale threats that affected birds breeding in different countries similarly.

The observed population decline rates are of a similar order of magnitude found for Egyptian Vultures in western Europe (Liberatori and Penteriani 2001, Sarà and Di Vittorio 2003, Grande et al. 2009), and it is likely that similar or more extreme declines have occurred in other Balkan

Table 2. Distribution and abundance of Egyptian Vultures in the Balkan Peninsula in 2013, separated into six spatially discrete concentrations of breeding territories ('population cluster', Figure. 2).

\begin{tabular}{lcc}
\hline Population cluster & Active territories in 2013 & Distance to nearest cluster \\
\hline Southern Albania/ western Greece & 12 & $150 \mathrm{~km}$ \\
Central Greece & 4 & $85 \mathrm{~km}$ \\
The FYR of Macedonia & 21 & $142 \mathrm{~km}$ \\
Southern Bulgaria/eastern Greece & 22 & $95 \mathrm{~km}$ \\
North-eastern Bulgaria & 6 & $120 \mathrm{~km}$ \\
European Turkey & 2 & $95 \mathrm{~km}$ \\
\hline
\end{tabular}


countries for which no quantitative data are available. The population declines in the Balkan Peninsula are apparently slower than those reported from India where diclofenac poisoning has devastated vulture populations since the 1990s (Green et al. 2004, Cuthbert et al. 2006, Prakash et al. 2012), but a direct comparison of the trends is not possible due to different survey and trend estimation approaches (territory monitoring vs. road counts in India; Cuthbert et al. 2006). Nonetheless, gradual changes in demographic parameters due to a growing variety of threats are a more likely underlying cause of population declines in the Balkans than the sudden appearance of a single lethal factor. Because the breeding performance of Balkan populations is largely comparable with productivity estimates from western European populations (for details see Kurtev et al. 2008, Mateo-Tomás et al. 2010, Grubač et al. 2014), the drivers of population declines are likely to be threats that reduce survival rates of adult and immature birds (Grande et al. 2009, Velevski et al. 2014). Understanding and mitigating the factors that reduce Egyptian Vulture survival is therefore the most pressing conservation challenge. Human activities have been shown to gradually alter the survival of immature and adult birds in other vulture species (Margalida et al. 2014b), and more research is now required to identify the key threats that cause Egyptian Vulture population declines.

Large-scale threats like accidental poisoning, electrocution, food shortages through changes in land use, pastoral systems, veterinary and sanitary practices and direct persecution, are likely to affect vultures on breeding grounds as well as along their migration routes and wintering areas (Thiollay 2006, Hernández and Margalida 2009, Virani et al. 2011, Angelov et al. 2013, Wacher et al. 2013). High adult and immature mortality during the migration and non-breeding season could explain the observed population declines in a long-lived species with delayed maturity such as the Egyptian Vulture (Carrete et al. 2007, Grande et al. 2009). A recent study of migrating raptors found that more than half of the annual mortality occurred on migration (Klaassen et al. 2014), and a similar pattern may exist for Egyptian Vultures. However, there is evidence that significant Egyptian Vulture mortality also occurs on breeding grounds (Kurtev et al. 2007, Grubač et al. 2014). For example, in the FYR of Macedonia approximately half of all recent losses for which the time of death was known have occurred in breeding territories (Grubač et al. 2014), and there are at least 16 known deaths of adult birds in Bulgaria and 11 more in Greece (most of them resulting from the accidental ingestion of poison baits) in the last 1o years (unpublished data of the Bulgarian Society for Protection of Birds and the Hellenic Ornithological Society). Although the use of poisonous baits is illegal under current EU legislation, the relevant laws are not properly enforced (Hernández and Margalida 2009, Margalida 2012). Direct persecution and disturbance at nest sites are also known to affect survival and reproductive output in the Balkans (Kurtev et al. 2008, Grubač et al. 2014), and hunting may be a significant threat along migration and in wintering areas (Klaassen et al. 2014). Lastly, the quality of breeding territories is likely to be affected by habitat loss due to infrastructure development, changes in agriculture and livestock breeding and veterinary practices, as well as garbage treatment (open garbage dumps are illegal and no longer available in EU countries; Xirouchakis and Tsiakiris 2009) and construction of energy production and transportation structures. Overall, there is a large and complex array of different threats that are likely to reduce the survival and - to a lesser extent - the annual productivity of Egyptian Vultures and thus account for the observed population declines.

The observed population declines across the Balkan Peninsula were associated with a range contraction and fragmentation into several clusters. A reduction of the breeding range has also been associated with population declines in mainland Italy and Sicily (Liberatori and Penteriani 2001, Sarà and Di Vittorio 2003), but not in Spain (Carrete et al. 2007), possibly because the Spanish population is still relatively large, and fragmentation has only recently begun to affect peripheral subpopulations (Donázar et al. 2009, Margalida et al. 2012). Our observation of a shrinking range is consistent with earlier reported extinctions farther north. Egyptian Vultures became extinct in Romania (Grubač 2005) and the Crimean Peninsula in the 1950s (last breeding 1958, Zubarovsky 1977, Kostin 1983), and from the Dniester region (Ukraine-Moldova) in the 1980s (Zhurminsky and Tsurkanu 2001, Tyschenkov 2004), indicating that population decline and range contraction started much earlier than any monitoring and conservation measures. The presence of conspecifics 
generally affects where young adults select a territory and recruit into the breeding population. In addition, higher-quality territories are usually occupied more consistently than those of poorer quality (Carrete et al. 2007), and will therefore attract conspecific recruits in their vicinity. The persistence and attraction of high-quality territories is the possible underlying mechanism behind the cluster formation in Egyptian Vulture territories in the Balkans, and is known in many other declining species (Lawton 1999). Nonetheless, Egyptian Vultures are known for their high natal philopatry (Carrete et al. 2007, Elorriaga et al. 2009, Grande et al. 2009), which may explain the persistence of remote territories, and may slow the range contraction. However, increasingly isolated clusters with few pairs face increasing extinction probability due to demographic, environmental, and potentially genetic stochasticity. These effects are exacerbated by the simultaneous decline of all major populations, rendering rescue effects from healthy source populations extremely unlikely. Very little is known about where immature Egyptian Vultures recruit into the breeding population in the Balkans, and more research is required to understand the causes of the fragmentation and increasing isolation of core breeding areas in the Balkan Peninsula. We recommend maintaining or improving annual monitoring of breeding populations and considering long-term individual marking studies to provide information about survival and recruitment of individuals into breeding populations.

In summary, we have shown that the Balkan population of Egyptian Vultures is declining rapidly across a large range. While the causes for these population declines are poorly understood, it is likely that poisoning, electrocution and direct persecution have affected survival and reproductive rates of Egyptian Vultures (Grubač 2005, Kurtev et al. 2007, Carrete et al. 2007, Grubač et al. 2014). All these factors operate at very large spatial scales, and alleviating these threats will require large-scale changes in human attitudes, activities and landscape use. Conservation activities that have been implemented in the Balkan Peninsula since 2003, have so far failed to reverse the population declines, presumably because they are too limited in geographic scale. Although supplementary feeding and other conservation interventions can help local populations (García-Ripollès and López-López 2006, Donázar et al. 2009, Margalida et al. 2014b), larger-scale policy and management changes are required to address the threats facing Egyptian Vultures across their range. We recommend the implementation and enforcement of anti-poisoning laws to reduce the accidental killing of scavenging birds across Europe and Africa, substitution of hazardous electrical infrastructure with safe structures across Europe, the Middle East and Africa to reduce electrocutions, and the retention of small-scale livestock grazing and carcass disposal systems that provide sufficient food for vultures. Certain non-steroidal anti-inflammatory drugs (e.g. diclofenac, ketoprofen) should be banned for veterinary use in Europe and Africa in order to reduce the risk of vulture mortality (Cuthbert et al. 2006, Naidoo et al. 2010, Margalida et al. 2014a). Identification and establishment of protected areas in the wintering range of the species where direct persecution and other threats are eliminated could potentially increase the survival rates of sub-adult and adult individuals (Velevski et al. 2014). Although implementing these policies and actions at a sufficiently large scale is a daunting challenge, there is hope that concerted efforts that address key threats to vultures may result in a stabilisation or recovery of endangered vulture populations if implemented at a sufficiently large scale (Donázar et al. 2009, Prakash et al. 2012, Galligan et al. 2014).

\section{Supplementary Material}

The online supplementary materials for this article can be found at journals.cambridge.org.bci

\section{Acknowledgements}

Many people assisted in monitoring efforts in various countries over the past decades, and our special thanks go to T. Lisičanec, E. Dimitrovska, B. Delov, M. Pop Trajkov, J. Andevski, S. Stefanovski, Ž. Brajanoski, D. Uzunova, E. Jordanovska, A. Todorovska, T. Bounas, D. Bousbouras, S. Bourdakis, K. Poirazidis, C. Ruiz, S. Schindler, P. Babakas, T. Skartsi, D. Vasilakis, A. Aptourahman, A. Christopoulos, T. Dimalexis, G. Rousopoulos, G. Catsadorakis, P. Azmanis, P. Konstantinou, 
N. Boukas, M. Diamantopoulos, K. Vlachopoulos, M. Pasiakos, P. Pavlidis, T. Angelova, I. Angelov, D. Demerdzhiev, P. Iankov, H. Hristov, M. Kurtev, S. Stoychev, S. Avramov, B. Stumberger, P. Knaus and D. Dobrev. D. Querido and E. Tabur contributed valuable discussions. M. Osipova provided some of the needed literature. A. Margalida, R. Moreno-Opo, J. A. Donázar and an anonymous referee provided valuable comments on the earlier drafts of the manuscript. We appreciate the financial support of the Black Vulture Conservation Foundation, Vulture Conservation Foundation and Frankfurt Zoological Society (for implementation of the field surveys and monitoring, through the Balkan Vulture Action Plan). This paper was initiated by the LIFE+ project "The Return of the Neophron" (LIFE1o NAT/BG/Ooo152, www.LifeNeophron.eu) funded by the European Union and co-funded by the A. G. Leventis Foundation.

\section{References}

Angelov, I., Hashim, I. and Oppel, S. (2013) Persistent electrocution mortality of Egyptian Vultures Neophron percnopterus over 28 years in East Africa. Bird Conserv. Internatn. 23: 1-6.

BirdLife International (2014) Neophron percnopterus. In IUCN (2014): IUCN Red List of Threatened Species. Version 2014.2. $<$ www.iucnredlist.org>. Downloaded on 05 August 2014.

Brooks, S. P. and Gelman, A. (1998) General methods for monitoring convergence of iterative simulations. J. Comput. Graph. Stat. 7: 434-455.

Carrete, M., Grande, J. M., Tella, J. L., SánchezZapata, J. A., Donázar, J. A., Díaz-Delgado, R. and Romo, A. (2007) Habitat, human pressure, and social behavior: Partialling out factors affecting large-scale territory extinction in an endangered vulture. Biol. Conserv. 136: 143-154.

Clark, J. S. and Bjørnstad, O. N. (2004) Population time series: process variability, observation errors, missing values, lags, and hidden states. Ecology 85: 3140-3150.

Cuthbert, R., Green, R. E., Ranade, S., Saravanan, S., Pain, D. J., Prakash, V. and Cunningham, A. A. (2006) Rapid population declines of Egyptian vulture (Neophron percnopterus) and red-headed vulture (Sarcogyps calvus) in India. Anim. Conserv. 9: 349-354.

De Valpine, P. (2003) Better inferences from population-dynamics experiments using Monte Carlo state-space likelihood methods. Ecology 84: 3064-3077.

Donázar, J. A. (2004) Alimoche Común Neophron percnopterus. Pp. 129-131 in A. Madroño, C. González and J. C. Atienza, eds. Libro rojo de las aves de España.
Madrid, Spain: Dirección General para la Biodiversidad and SEO BirdLife.

Donázar, J. A., Margalida, A. and Campión, D., eds. (2009) Vultures, feeding stations and sanitary legislation: a conflict and its consequences from the perspective of conservation biology. MUNIBE Suplemento/ Gehigarria 29. Donostia, Spain: Sociedad de Ciencias Aranzadi.

Elorriaga, J., Zuberogoitia, I., Castillo, I., Azkona, A., Hidalgo, S., Astorkia, L., Ruiz-Moneo, F. and Iraeta, A. (2009) First documented case of long-distance dispersal in the Egyptian Vulture (Neophron percnopterus). J. Raptor Res. 43: 142-145.

Galligan, T. H., Amano, T., Prakash, V. M., Kulkarni, M., Shringarphure, R., Prakash, N., Ranade, S., Green, R. E. and Cuthbert, R. J. (2014) Have population declines in Egyptian Vulture and Red-headed Vulture in India slowed since the 2006 ban on veterinary diclofenac? Bird Conserv. Internatn. 24: 272-281.

García-Ripollès, C. and López-López, P. (2006) Population size and breeding performance of Egyptian vultures (Neophron percnopterus) in Eastern Iberian Peninsula. J. Raptor Res. 40: $217-221$.

Grande, J. M., Serrano, D., Tavecchia, G., Carrete, M., Ceballos, O., Díaz-Delgado, R., Tella, J. L. and Donázar, J. A. (2009) Survival in a longlived territorial migrant: effects of life-history traits and ecological conditions in wintering and breeding areas. Oikos 118: 580-590.

Green, R. E., Newton, I., Shultz, S., Cunningham, A. A., Gilbert, M., Pain, D. J. and Prakash, V. (2004) Diclofenac poisoning as a cause of vulture population declines across the Indian subcontinent. J. Appl. Ecol. 41: 793-800. 
Grubač, B. R. (1989) The Egyptian Vulture Neophron percnopterus in Macedonia. Pp. 331-333 In B. U. and C. R. D. Meyburg, eds. Raptors in the modern world. Berlin, London and Paris: WWGBP.

Grubač, B. R. (1999) The Egyptian Vulture Neophron percnopterus (Linnaeus, 1758) in Serbia. Protection of Nature 51: 123-131.

Grubač, B. R. (2000) The present status of vultures Aegypiinae in Central Balkans. Pp. 93-103. In: Actas del II congreso internacional sobre Aves Carroñeras, 1997. Cuenca, Spain: Cañizares-Solán de Cabras.

Grubač, B. R. (2005) Artificial feeding places and the conservation of vultures and other scavenging birds in Serbia. Vulture News 52: 10-24.

Grubač, B., Velevski, M. and Avukatov, V. (2014) Long-term population decline and recent breeding performance of the Egyptian Vulture Neophron percnopterus in Macedonia. North-Western J. Zool. 10: 25-35.

Handrinos, G. and Akriotis, T. (1997) The birds of Greece. London: Christopher Helm.

Hernández, M. and Margalida, A. (2009) Poisonrelated mortality effects in the endangered Egyptian vulture (Neophron percnopterus) population in Spain. Eur. J. Wildl. Res. 55: 415-423.

Iñigo, A., Barov, B., Orhun, C. and Gallo-Orsi, U. (2008) Action plan for the Egyptian Vulture Neophron percnopterus in the European Union. Brussels, Belgium: BirdLife International and European Commission.

Kéry, M. and Schaub, M. (2012) Bayesian population analysis using WinBUGS: A hierarchical perspective. Academic Press.

Klaassen, R. H. G., Hake, M., Strandberg, R., Koks, B. J., Trierweiler, C., Exo, K.-M., Bairlein, F. and Alerstam, T. (2014) When and where does mortality occur in migratory birds? Direct evidence from long-term satellite tracking of raptors. J. Anim. Ecol. 83: $176-184$.

Kostin, Y. V. (1983) Birds of the Crimea. Moscow: Nauka.

Kurtev, M., Angelov, I., Demerdjiev, D., Stoynov, E., Iankov, P. and Hristov, H. (2007) Egyptian Vulture Neophron percnopterus. Pp. 132-133 in P. Iankov, ed. Atlas of breeding birds in Bulgaria. Sofia: Bulgarian Society for Protection of Birds.
Kurtev, M., Iankov, P. and Angelov, I. (2008) National action plan for conservation of the Egyptian Vulture (Neophron percnopterus) in Bulgaria. Sofia: Bulgarian Society for Protection of Birds.

Lawton, J. H. (1999) Are there general laws in ecology? Oikos 84: 177-192.

Liberatori, F. and Penteriani, V. (2001) A longterm analysis of the declining population of the Egyptian vulture in the Italian peninsula: distribution, habitat preference, productivity and conservation implications. Biol. Conserv. 101: $381-389$.

Ljucović, V. (1995) For the birds of the canyon of river Cijevna and the mountain Kaženik in the eastern Montenegro. Ciconia 5: 67-68.

Margalida, A. (2012). Baits, budget cuts: A deadly mix. Science 338: 192-192.

Margalida, A., Benítez, J. R., Sánchez-Zapata, J. A., Ávila, E., Arenas, R. and Donázar, J. A. (2012) Long-term relationship between diet breadth and breeding success in a declining population of Egyptian Vultures Neophron percnopterus. Ibis 154: 184-188.

Margalida, A., Sánchez-Zapata, J. A., Blanco, G., Hiraldo, F. and Donázar, J. A. (2014a) Diclofenac approval as a threat to Spanish vultures. Conserv. Biol. In press.

Margalida, A., Colomer, M. À. and Oro, D. (2014b) Man-induced activities modify demographic parameters in a long-lived species: effects of poisoning and health policies. Ecol. Appl. 24: 436-444.

Marinković, S., Orlandić, L., Micković, B. and Karadžić, B. (2007) Census of vultures in Herzegovina. Vulture News 56: 14-28.

Mateo-Tomás, P., Olea, P. P. and Fombellida, I. (2010) Status of the Endangered Egyptian vulture Neophron percnopterus in the Cantabrian Mountains, Spain, and assessment of threats. Oryx 44: 434-440.

Naidoo, V., Wolter, K., Cromarty, D., Diekmann, M., Duncan, N., Meharg, A. A., Taggart, M.A., Venter, L. and Cuthbert, R. (2010) Toxicity of non-steroidal anti-inflammatory drugs to Gyps vultures: a new threat from ketoprofen. Biol. Lett. 6: 339-341.

Nisbet, I. C. T. and Smout, T. C. (1957) Autumn observations on the Bosphorus and Dardanelles. Ibis 99: 483-499.

Ogada, D. L., Keesing, F. and Virani, M. Z. (2012) Dropping dead: causes and consequences of 
vulture population declines worldwide. Ann. N. Y. Acad. Sci. 1249: 57-71.

Patev, P. (1950) The birds of Bulgaria. Sofia: Bulgarian Academy of Sciences.

Plummer, M. (2012) JAGS version 3.3.0. http:// sourceforge.net/projects/mcmc-jags/files/ Manuals/

Poirazidis, K., Schindler, S., Kakalis, E., Ruis, C., Bakaloudis, D. E., Scandolara, C., Eastham, C., Hristov, H. and Catsadorakis, G. (2011) Population estimates for the diverse raptor assemblage of Dadia National Park, Greece. Ardeola 58: 3-17.

Prakash, V., Bishwakarma, M. C., Chaudhary, A., Cuthbert, R., Dave, R., Kulkarni, M., Kumar, S., Paudel, K., Ranade, S., Shringarpure, R. and Green, R. E. (2012) The population decline of Gyps vultures in India and Nepal has slowed since veterinary use of diclofenac was banned. PLoS ONE 7: e49118.

Prakash, V., Pain, D. J., Cunningham, A. A., Donald, P. F., Prakash, N., Verma, A., Gargi, R., Sivakumar, S. and Rahmani, A. R. (2003) Catastrophic collapse of Indian white-backed Gyps bengalensis and Long-billed Gyps indicus vulture populations. Biol. Conserv. 109: 381-390.

R Core Team (2013) R: A language and environment for statistical computing. Vienna, Austria: R Foundation for Statistical Computing. http://www.r-project.org

Sarà, M. and Di Vittorio, M. (2003) Factors influencing the distribution, abundance and nest-site selection of an endangered Egyptian vulture (Neophron percnopterus) population in Sicily. Anim. Conserv. 6: 317-328.

Skartsi, T., Vasilakis, D. and Elorriaga, J. (2010) Population trends and conservation of vultures in the Dadia-Lefkimi-Soufli Forest National Park. Pp. 183-193 in The DadiaLefkimi-Soufli Forest National Park, Greece: Biodiversity, Management and Conservation.

Su, Y.-S., and Yajima, M. (2012) R2jags: $A$ package for running jags from $R$. R package version 0.03-08, http://CRAN.R-project.org/ package $=$ R 2 jags

Sušić, G. (1993) Re-introducing extinct bird species to areas in Croatia - utopia or reality? Soc. Ecol. Zagreb 2: 91-97.

Thiollay, J. (2006) The decline of raptors in West Africa: long-term assessment and the role of protected areas. Ibis 148: 240-254.
Thiollay, J. M. (2007) Raptor population decline in West Africa. Ostrich 78: 405-413.

Tyschenkov, A. A. (2004) Records of some rare bird species in the Dniester region in 2003. Berkut 13: 131-132.

Velevski, M., Grubač, B. and Tomović, L. (2014) Population viability analysis of the Egyptian Vulture Neophron percnopterus in Macedonia and implications for its conservation. Acta Zool. Bulg. 66: $43-58$.

Virani, M. Z., Kendall, C., Njoroge, P. and Thomsett, S. (2011) Major declines in the abundance of vultures and other scavenging raptors in and around the Masai Mara ecosystem, Kenya. Biol. Conserv. 144: 746-752.

Vlachos, C. G., Papageorgiou, N. K. and Bakaloudis, D. E. (1998) Effects of the feeding station establishment on the Egyptian Vulture Neophron percnopterus in Dadia Forest, North Eastern Greece. Pp. 197-207 In R. D. Chancellor, B. -U. and Meyburg and J. J. Ferrero, eds. Holarctic birds of prey, Proceedings of an international conference. Mérida and Berlin: ADENEX-WWGBP.

Wacher, T., Newby, J., Houdou, I., Harouna, A. and Rabeil, T. (2013) Vulture observations in the Sahelian zones of Chad and Niger. Bull ABC 20: 286-199.

Wilson, H. B., Kendall, B. E. and Possingham, H. P. (2011) Variability in population abundance and the classification of extinction risk. Conserv. Biol. 25: 747-757.

Xirouchakis, S. and Tsiakiris, R. (2009) Status and population trends of vultures in Greece. Pp. 160-177 in J. A. Donázar, A. Margalida and D. Campion, eds. Vultures, feeding stations and sanitary legislation: a conflict and its consequences from the perspective of conservation biology. MUNIBE Suplemento/ Gehigarria 29. Donostia, Spain: Sociedad de Ciencias Aranzadi.

Zhurminsky, S. D. and Tsurkanu, V. F. (2001) Birds and reptiles of Lower Reut River and their environment. Pp. 120-103 In Geoecological and bioecological problems of Northern Black Sea Region, Proceedings of international conference. Tiraspol: Tiraspol State University.

Zubarovsky, V. M. (1977) Fauna of Ukraine. Birds of prey. Kiev: Naukova dumka. 
METODIJA VELEVSKI*

Macedonian Ecological Society, PO Box 162, 10oo Skopje, the FYR of Macedonia.

STOYAN C. NIKOLOV, VLADIMIR DOBREV, VOLEN ARKUMAREV

Bulgarian Society for Protection of Birds / BirdLife Bulgaria, Yavorov complex, bl. 71, vh. 4, PO box 50, 1111 Sofia, Bulgaria.

BRATISLAV GRUBAČ

Institute for Nature Conservation of Serbia, Voždova 14, 18000 Niš, Serbia.

STEFFEN OPPEL

RSPB Centre for Conservation Science, Royal Society for the Protection of Birds, The Lodge,

Sandy, Bedfordshire SG19 2DL, UK.

KALLIOPI STARA

Laboratory of Ecology, Department of Biological Applications and Technology, University of Ioannina, University Campus, 45110, Ioannina, Greece, and Hellenic Ornithological Society, Themistokleous 80, GR-10681 Athens, Greece.

ELZBIETA KRET

WWF Greece, 21 Lambessi, Gr 11743 Athens, Greece.

RIGAS TSIAKIRIS

Forestry Service of Ioannina, M. Kotopouli 62, Ioannina, 45445 Greece.

BEN HALLMANN

40008 Rapsani, Greece.

LAVRENTIS SIDIROPOULOS, VICTORIA SARAVIA, THANOS KASTRITIS, DIMITRIS VAVYLIS

Hellenic Ornithological Society, Themistokleous 80, GR-10681 Athens, Greece.

ANTONIA GALANAKI

Eressou 35, GR-10681 Athens, Greece.

THEODOROS KOMINOS

Management Authority of Kalamas and Acherontas Gorges and Deltas, Eirinis kai Filias 1, GR-4610o Igoumenitsa, Greece.

EMANUEL LISIČANEC

Nature Conservation Association "Aquila", Belasica 3, 140o Kavadarci, the FYR of Macedonia.

MIRJAN TOPI, BLEDI HOXHA

Protection and Preservation of Natural Environment in Albania, Rr. Vangjush Furrxhi, Pall 16, Shk 1, Ap 10, 1000 Tirana, Albania.

*Author for correspondence; email: velevski@mes.org.mk

Received 25 March 2014; revision accepted I September 2014; Published online 5 December 2014 